\title{
Single massive thoracolithiasis
}

\author{
Peter Bill Juul Ladegaard, ${ }^{1}$ Lars Ladegaard, ${ }^{2}$ Rasmus Carter-Storch, ${ }^{3}$ \\ Nicolaj Lyhne Christensen (i) ${ }^{1}$
}

'Department of Radiology, University Hospital of Odense, Odense C, Denmark ${ }^{2}$ Department of Thoracic Surgery, University Hospital of Odense, Odense C, Denmark ${ }^{3}$ Department of Cardiology, University Hospital of Odense, Odense C, Denmark

\section{Correspondence to}

Mr Nicolaj Lyhne Christensen; nicolaj.christensen@rsyd.dk

Accepted 1 July 2020

\section{DESCRIPTION}

A 72-year-old man was referred to a chest X-ray due to persistent coughing, intermittent dyspnoea and atypical chest pain. The radiology report mentioned a $4 \mathrm{~cm}$ inhomogeneous opacity at the anterior right lower lung field (figure 1A). Subsequently, a CT scan of the thorax and upper abdomen revealed a sharply demarcated process located in the inferior medial part of the right major lung fissure (figure 1B). A positron emission tomography and computed tomography (PET-CT) scan displayed no FDG uptake. The patient was planned for elective video-assisted thoracoscopic surgery (VATS). Prior to surgery another CT scan showed that the process had migrated to the lateral aspect of the right minor fissure (figure 2A). VATS revealed a whitish excessively large entity with a smooth surface measuring $4 \times 3 \times 2 \mathrm{~cm}$ with no attachment to the lung or pleura (figure $2 \mathrm{~B}$ ). Thus, a mobile free body in the pleural space consistent with thoracolithiasis. One year earlier the patient had a normal thoracic CT scan. After surgical removal microscopic examination of the entity showed central calcification and mainly connective tissue fibres arranged in parallel with sparse cells.

Thoracoliths are mobile bodies in the pleural space and they are often encountered incidentally on $\mathrm{CT}$ chest examination. Cases of thoracolithiasis are rare and have been reported during the last decades including cases with both unilateral and bilateral multiple thoracoliths. ${ }^{1-3}$ To our knowledge this is
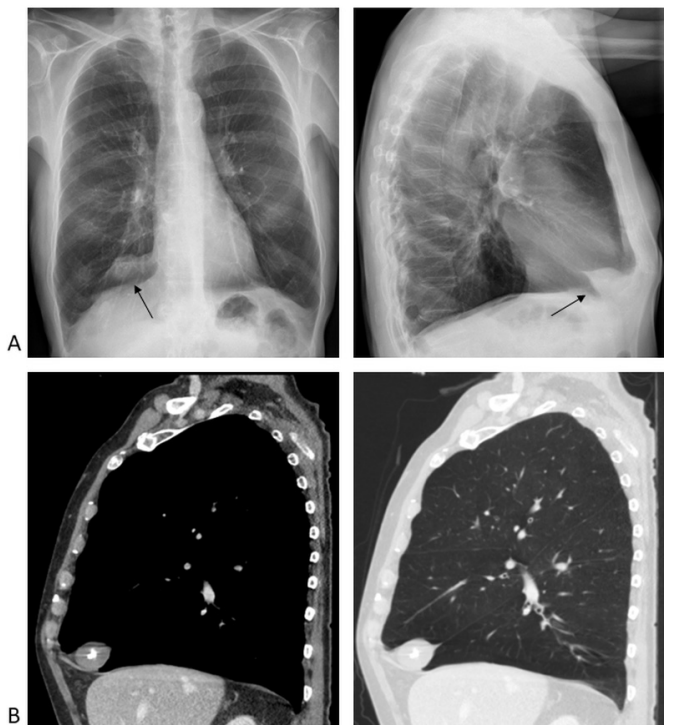

Figure 1 (A) Chest X-ray. Thoracolith (black arrow) with central calcification. (B) CT scan sagittal view - primary scan.
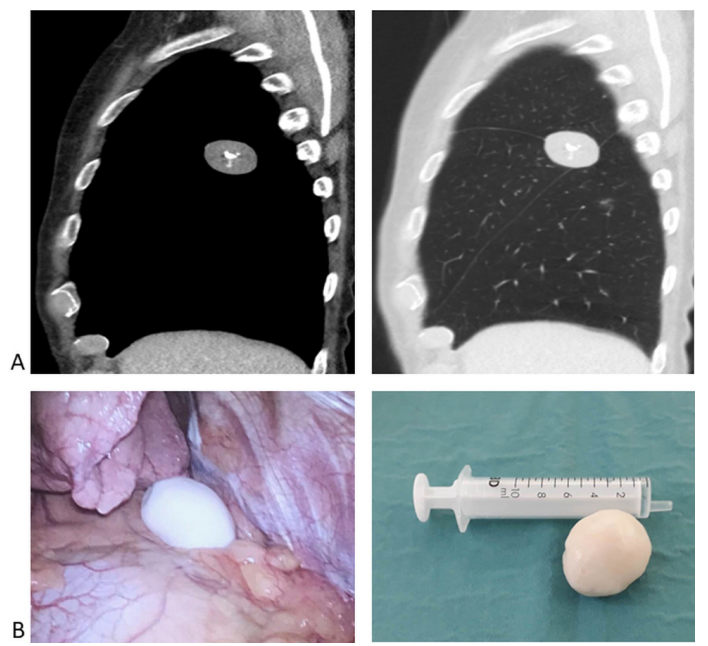

Figure 2 (A) CT scan sagittal view - prior to surgery. (B) Perioperative images of thoracolithiasis.

the largest thoracolith reported. They usually range from 5 to $15 \mathrm{~mm}$ in size with some degree of calcification, but seldom they are very large. Thus, they are not reported on standard chest X-rays as they are masked by the nearby diaphragm as they hide deep in gravity-dependent locations. ${ }^{4}$ The aetiology remains unknown, but thoracoliths are believed to be formed of lipomas, necrotic pleural tissue, a granulomatous process or macrophage aggregation. The exact time frame in which thoracolithiasis is formed is unclear. This case demonstrates a 1 year time span for the formation of a single very large thoracolith. Main differential diagnosis is granuloma, but other pathologies should be considered such as primary lung tumours, sarcomas, metastases and hamartomas. ${ }^{5}$

Thoracolithiasis is a benign condition with mobile elements in the pleural space and patients are usually asymptomatic. Location may vary on serial imaging and is pathognomonic for this condition. Gravity dependent location, calcification and

\section{Learning points}

- Thoracolithiasis is a benign and rare condition with one or more mobile free bodies in the pleural space.

- Thoracoliths usually measure between 5 to 15 $\mathrm{mm}$ and they often contain some degree of calcification.

- Thoracoliths are likely to be under-reported, and when small in size, they may mimic other benign or malignant pathologies of the lung. 
mobility of a mass demonstrated on serial CT imaging all play a central role in diagnosis. Occasionally, surgical removal is necessary for definite confirmation but, in general, treatment is not recommended.

The patient was discharged from hospital within a few days after an uneventful course.

Contributors $\mathrm{PL}, \mathrm{LL}$ and NC participated in the diagnosis and the management of the patient. PL, LL, RCS and NC discussed the manuscript and results and contributed to the final manuscript. PL, LL and RCS took part in designing and preparing the manuscript under the guidance of NC.

Funding The authors have not declared a specific grant for this research from any funding agency in the public, commercial or not-for-profit sectors.

Competing interests None declared.
Patient consent for publication Obtained.

Provenance and peer review Not commissioned; externally peer reviewed.

\section{ORCID iD}

Nicolaj Lyhne Christensen http://orcid.org/0000-0002-4895-0588

\section{REFERENCES}

1 Ogushi A, Sugioka T, Nishiyama M. Thoracolithiasis. J Gen Fam Med 2019;20:122-3.

2 Bhayana R, Chen YA, Deva DP. Bilateral mobile Thoracolithiasis. J Radiol Case Rep 2014;8:16-20.

3 Hochhegger B, Camargo SM, Nascimento D, et al. Thoracolithiasis: a rare cause of multiple nodules. Am J Respir Crit Care Med 2018:197:1212-3.

4 Kinoshita F, Saida Y, Okajima Y, et al. Thoracolithiasis: 11 cases with a calcified intrapleural loose body. J Thorac Imaging 2010;25:64-7.

5 Khan A, Al-Jahdali H, Allen C, et al. The calcified lung nodule: what does it mean? Ann Thorac Med 2010:5:67-79.

Copyright 2020 BMJ Publishing Group. All rights reserved. For permission to reuse any of this content visit

https://www.bmj.com/company/products-services/rights-and-licensing/permissions/

BMJ Case Report Fellows may re-use this article for personal use and teaching without any further permission.

Become a Fellow of BMJ Case Reports today and you can:

- Submit as many cases as you like

- Enjoy fast sympathetic peer review and rapid publication of accepted articles

Access all the published articles

Re-use any of the published material for personal use and teaching without further permission

Customer Service

If you have any further queries about your subscription, please contact our customer services team on +44 (0) 2071111105 or via email at support@bmj.com.

Visit casereports.bmj.com for more articles like this and to become a Fellow 